\title{
アルミニウム合金/鋼スポット溶接部の 界面組織と強度について
}

\section{王楠1,* 山口富子 子 $^{2}$ 西尾一政 ${ }^{3}$}

\author{
1九州工業大学大学院生命体工学研究科 \\ 2九州工業大学大学院工学府 \\ 3 西日本工業大学
}

J. Japan Inst. Met. Mater. Vol. 77, No. 7 (2013), pp. 259-267

(C) 2013 The Japan Institute of Metals and Materials

\section{Interfacial Microstructure and Strength of Aluminum Alloys/Steel Spot Welded Joints}

\author{
Nan Wang ${ }^{1, *}$, Tomiko Yamaguchi ${ }^{2}$ and Kazumasa Nishio ${ }^{3}$ \\ ${ }^{1}$ Graduate School of life Science and Systems Engineering, Kyushu Institute of Technology, Kitakyushu 808-0196 \\ ${ }^{2}$ Faculty of Engineering, Kyushu Institute of Technology, Kitakyushu 804-8550 \\ ${ }^{3}$ Nishinippon Institute of Technology, Miyako-gun, Fukuoka 800-0394
}

In order to reduce carbon emission, aluminum alloy has been being considered to get light weight car body in automotive industry. But it is difficult to obtain highly reliable joint of aluminum alloy and steel because of the production of hard and brittle intermetallic compounds during the welding process. In this study, aluminum alloys were welded to cold-rolling steel SPCC by resistance spot welding. Effects of welding conditions and alloy element $\mathrm{Si}, \mathrm{Cu}$ and $\mathrm{Mg}$ in aluminum alloy on growth of intermetallic compounds at weld interfacial zones and weld strength of aluminum alloys/SPCC joints were investigated. The intermetallic compound layer was formed of $\mathrm{Fe}_{2} \mathrm{Al}_{5}$ adhering to the steel and $\mathrm{FeAl}_{3}$ adhering to aluminum alloy, and the thickness varied with positions along the interface. From EBSD results, the $\mathrm{Fe}_{2} \mathrm{Al}_{5}$ layer has columnar grains which grew with the $\langle 001\rangle$ direction perpendicular to the interface of spot welded joint. Diffusion of Si in aluminum alloy happened at the interface, which might inhibit the growth of intermetallic compounds, whereas diffusion of $\mathrm{Mg}$ and $\mathrm{Cu}$ was not found at the interface by EPMA analysis results. Hardness of intermetallic compound $\mathrm{Fe}_{2} \mathrm{Al}_{5}$ was affected by the diffusion of $\mathrm{Si}$ in aluminum alloy. The tensile shear strength of joint increased with the increasing of welding time, and the maximum tensile shear load was obtained at welding time of $0.134 \mathrm{~s}$ and 0.167 s. [doi: $10.2320 /$ jinstmet.J2012070]

(Received December 7, 2012; Accepted April 2, 2013; Published July 1, 2013)

Keywords: resistance spot welding, intermetallic compound, aluminum alloy and steel, tensile shear test, electron backscattered diffraction $(E B S D)$

\section{1. 緒言}

地球温暖化などの深刻な環境問題により，自動車産業で は，車体の軽量化を図るため，アルミニウム合金などの軽金 属の採用が図られているが，アルミニウム合金のみで車を製 造するには，コスト面や強度の面で問題が生じる。これを解 決するために，最近ではアルミニウム合金と鋼を適材適所に 活用する「材料ハイブリッド構造」が検討されている1-5).

アルミニウム合金と鋼の異種金属接合は, 摩擦攪拌接 合 $^{6)}$, レーザ溶接 ${ }^{7)}$, 固相拡散接合8)などの接合技術を用い て検討されている.しかしながら, アルミニウムと鋼の溶接 界面には脆弱な金属間化合物 (以後 IMC と記す)が形成さ れ, 信頼性の高い継手が得られない。この改善策として界面 組織制御が重要になる。 $\mathrm{Al} / \mathrm{Fe}$ の IMC については, 様々な
分野の研究者が報告している. Hot dip 法により, Fe 基 $\mathrm{Al}$ コーティング材の作製においてはアルミニウム合金にシリコ ンを添加することによって界面反応層の厚さが減少する ${ }^{9)}$. 固相拡散接合法を用いたアルミニウム合金と低炭素鋼の異種 金属継手に抢いて，アルミニウム合金にシリコンと銅を添加 することによって界面反応層が改善される報告もある10,11). 著者らは，真空圧延接合法を用いてアルミニウム合金/鋼ク ラッド材を作製し, そのクラッド材に熱処理を施し, この際 の IMC の厚さに及ぼすアルミニウム合金中の $\mathrm{Si}, \mathrm{Cu}$ 抢よび $\mathrm{Mg}$ の影響について検討している12). しかし，スポット溶接 部の特性に及ぼす合金元素の影響についてはあまり報告され ていない.

そこで, 本研究では, 化学組成が異なるアルミニウム合金 と一般冷間圧延鋼板 SPCC とのスポット溶接部の組織およ び溶接部強度に及ぼす溶接条件および合金元素の影響につい て検討した.

\footnotetext{
* 九州工業大学大学院生 (Graduate Student, Kyushu Institute of Technology)
} 
Table 1 Chemical compositions, solidus temperature and hardness of aluminum alloys used.

\begin{tabular}{|c|c|c|c|c|c|c|c|c|}
\hline Materials & $\mathrm{Si}$ & $\mathrm{Fe}$ & $\mathrm{Cu}$ & $\mathrm{Mg}$ & $\mathrm{Ti}$ & $\mathrm{Al}$ & $\begin{array}{l}\text { Solidus } \\
\text { temperature (TG-DTA), } T / \mathrm{K}\end{array}$ & $\begin{array}{l}\text { Hardness, } \\
\text { HV }\end{array}$ \\
\hline $\mathrm{N} 2$ & 0.15 & 0.03 & 0.49 & 4.52 & 0.01 & Bal. & 838 & 62 \\
\hline N5 & 0.39 & 0.03 & 0.03 & 2.48 & 0.01 & Bal. & 866 & 45 \\
\hline N6 & 0.40 & 0.03 & 0.49 & 2.45 & 0.01 & Bal. & 857 & 44 \\
\hline
\end{tabular}

Table 2 Chemical compositions of SPCC used.

(mass\%)

\begin{tabular}{cccccc}
\hline Material & $\mathrm{C}$ & $\mathrm{Si}$ & $\mathrm{Mn}$ & $\mathrm{P}$ & $\mathrm{S}$ \\
\hline SPCC & 0.07 & 0.013 & 0.36 & 0.014 & 0.009 \\
\hline
\end{tabular}

\section{2. 使用材料および実験方法}

本実験では合金元素 $\mathrm{Si}, \mathrm{Cu}$ および $\mathrm{Mg}$ の影響を調査する ため, Table 1 に示す化学組成のアルミニウム合金 N2, N5

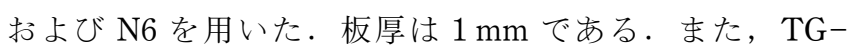
DTA 法により測定したアルミニウム合金の固相線温度およ びそれぞれのアルミニウム合金(焼なまし材)の硬さも Table 1 に示す. 鋼は板厚 $1 \mathrm{~mm}$ の一般冷間圧延鋼板 SPCC を使用 した. Table 2 に化学組成を示す.

抵抗スポット溶接には，アロー陎製単相交流式定置型スポ ット溶接機 $(\mathrm{AS}-100)$ を用いた。仕様は定格一次電圧 220 $\mathrm{V}$, 最大短絡電流 $26 \mathrm{kA}$, 定格周波数 $60 \mathrm{~Hz}$, 最大加圧力 $4.9 \mathrm{kN}$ である. 電極は, クロム銅製で曲率半径 $R 75$ の電極 を用いた。

スポット溶接の前処理としては，アルミニウム合金と鋼の 被溶接面をエメリー紙（\#100）で研磨および脱脂した。溶接 条件は, 溶接電流 $I$ を $10.5 \mathrm{kA}$, 溶接加圧力 $F$ を $1 \mathrm{kN}$ と一 定にして，溶接時間 $t$ を $0.067 \sim 0.200 \mathrm{~s}(4 \sim 12$ cycle ) として 溶接を行った。 また, 溶接界面に生成した IMC の組織観察 および硬さを測定するため, 溶接時間を $t=0.400 \mathrm{~s}$ と長くし て溶接を行った.

溶接部のほぼ中央断面において, 光学顕微鏡 $(\mathrm{OM})$ および 電界放射型電子顕微鏡 $(\mathrm{FE}-\mathrm{SEM})$ を用いて, 溶接部のミク ロ組織を観察した. IMC の厚さを測定する際, 1000 倍の写 真を用い， 1 視野につき約 $8 \mu \mathrm{m}$ 間隔に 10 力所の厚さを測 定した。アルミニウム合金とSPCC との溶接界面に打い て，電界放射電子線マイクロアナライザ(FE-EPMA)により 分析を行い，溶接部の合金元素の拡散状況を調査した．本研 究で用いた EPMA 分析装置の電子線スポット径は約 $0.1 \mu \mathrm{m}$ である. IMCの結晶構造を調査するため, 溶接部において EBSD (Electron Backscattered Diffraction)解析を行った.

IMC の硬さを調べるため, ナノインデンテーションによ って硬さを測定した。 また, 溶接部強度を調査するために, 各条件で 4 本ずつの試験片を用意し, 島津試験機サービス 侏製のオートグラフ $(\mathrm{AG}-10 \mathrm{TD})$ を用いて，クロスヘッドス

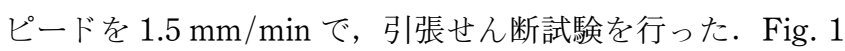
に引張せん断試験片の形状および寸法を示す.引張破断後, 破断位置を調査するため，EPMA 抢よびエネルギー分散型 $\mathrm{X}$ 線分光器 (EDS) を用いて, 引張せん断破面に抢ける組織
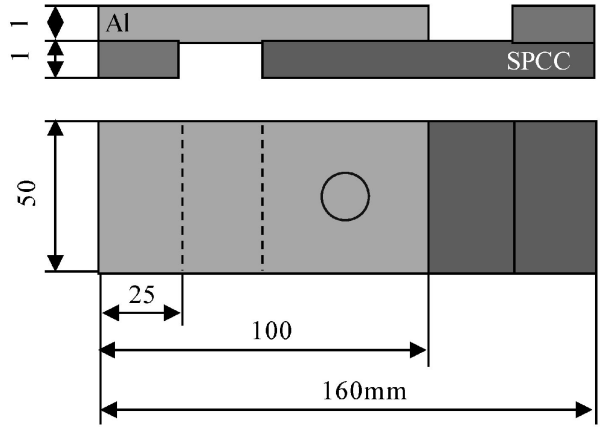

Fig. 1 Shape and dimensions of piece for tensile shear test.

観察ならびに組成分析を行った.

\section{3. 実験結果および考察}

\section{1 溶接部における IMC の組織および結晶構造}

\subsubsection{IMC のミクロ組織の観察}

Fig. 2 に観察位置の略図を示す. 観察位置はナゲットの半 径を $r=1$ としたとき, $r=0$ はナゲット中心部, $r=1 / 2$ はナ ゲット中心部と外周部の中間部, $r=1$ はナゲット外周部で あり,これらの 3 箇所を観察した. Fig. 3 に溶接時間 $t=$ $0.167 \mathrm{~s}$ の場合の N2/SPCC の溶接界面に抢けるミクロ組織 を示す。観察位置によって，IMCの形状および厚さは異な ることが分かる．IMC は，ナゲットの中央部 $r=0$ のところ でほぼ均一に生成し， $r=1 / 2$ のところで SPCC 側に向って 厚く舌状に生成し， $r=1$ のところでは薄くほぼ均一に生成 している.

IMC は一層で構成されているように見えるが，溶接時間 を $t=0.400 \mathrm{~s}$ と長くして溶接した場合の溶接部を高倍率で観 察すると, Fig. 4 に示すように, 二層の IMC の生成が認め られる. N2 アルミニウム合金側に, 約 $0.3 \mu \mathrm{m}$ の針状 IMC がアルミニウム側に向って生成し, SPCC 鋼側には不均一な 舌状の IMC が鋼側に向って生成している.

\subsubsection{IMC の同定}

スポット溶接部近傍の元素の濃度分布を調査するため, EPMA 分析を行った. Fig. 5 に $t=0.167 \mathrm{~s}$ の溶接時間でス ポット溶接を行った場合の N2/SPCCの溶接部に打ける EPMA による線分析の結果を示すＮN2アルミニウム合金と SPCCの界面付近に拈いて $\mathrm{Al}$ と $\mathrm{Fe}$ の濃度の混合領域が見 られ，IMCの形成が認められる，ZAF 補正により，IMCは $\mathrm{FeAl}_{3}$ および $\mathrm{Fe}_{2} \mathrm{Al}_{5}$ と考えられる.

Fig. 6 に N2/SPCC 溶接部引張せん断破面の N2 側および SPCC 側におけるXRD 分析結果を示す. 2 種類の金属間化 合物 $\mathrm{Fe}_{2} \mathrm{Al}_{5}$ および $\mathrm{FeAl}_{3}$ が同定された。この結果と EPMA 


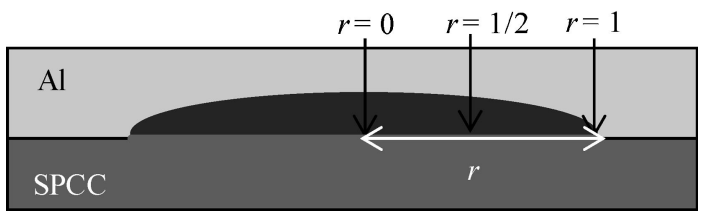

Fig. 2 Schematic diagram of spot welded joint.
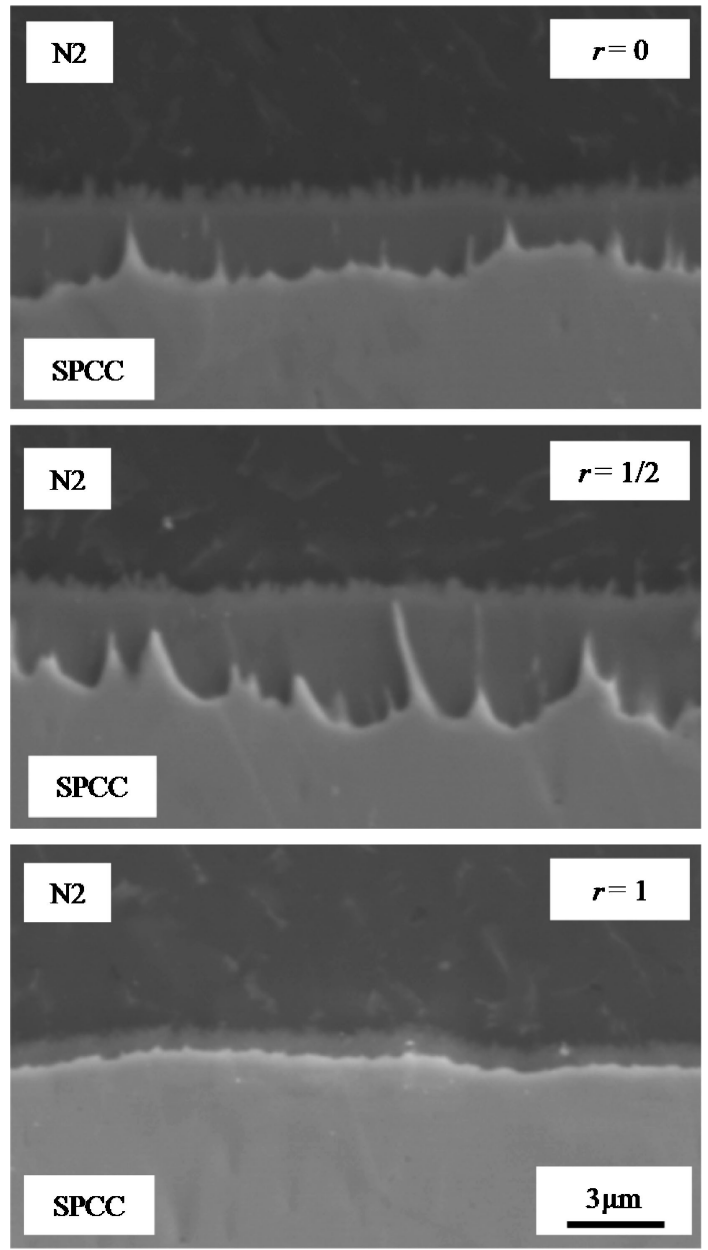

Fig. 3 Microstructures on weld interface of N2/SPCC spot welded joint $(\mathrm{N} 2 / \mathrm{SPCC}, 10.5 \mathrm{kA} \times 1 \mathrm{kN} \times 0.167 \mathrm{~s})$.

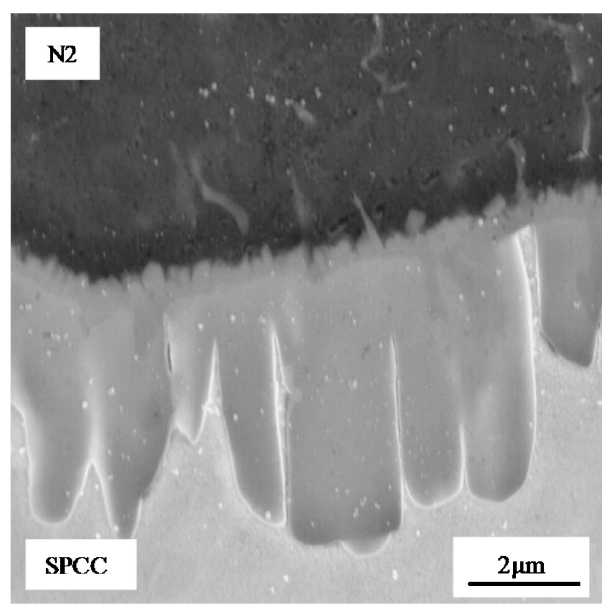

Fig. 4 Magnified micrograph at the position of $r=1 / 2$ using FE-SEM $(\mathrm{N} 2 / \mathrm{SPCC}, 10.5 \mathrm{kA} \times 1 \mathrm{kN} \times 0.400 \mathrm{~s})$.

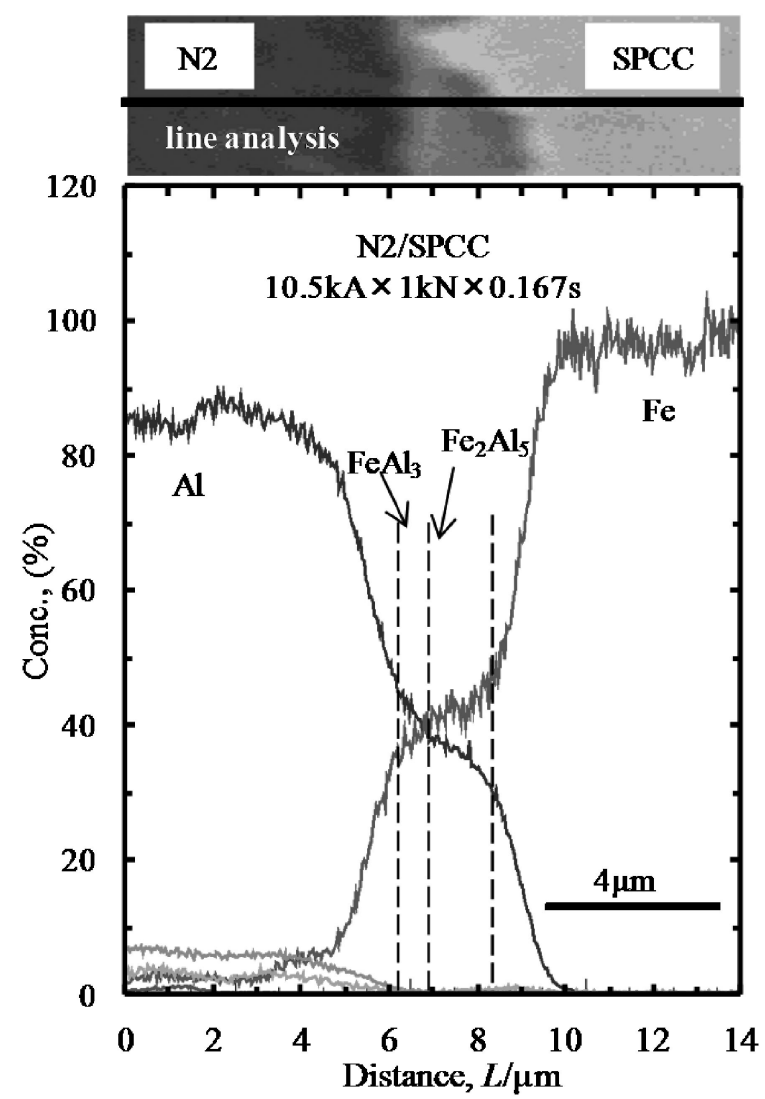

Fig. 5 Result of EPMA line analysis on weld interface of N2 aluminum alloy/SPCC $(\mathrm{N} 2 / \mathrm{SPCC}, 10.5 \mathrm{kA} \times 0.167 \mathrm{~s})$.

の結果とが合致した。つまり，アルミニウム合金と鋼をスポ ット溶接した際に生成したアルミニウム合金側の針状の IMC は $\mathrm{FeAl}_{3}$ であり，鋼側の舌状の IMC は $\mathrm{Fe}_{2} \mathrm{Al}_{5}$ である ことが分かった。この結果は，R. Qiuらおよび迎らの結果 々同様である13-16).

\subsubsection{IMC の結晶構造解析}

本研究では， $\mathrm{Fe}_{2} \mathrm{Al}_{5}$ 相の結晶構造のデータを用い， $\mathrm{EBSD}$ 解析を行った。しかし, $\mathrm{FeAl}_{3}$ 相は約 $0.3 \mu \mathrm{m}$ と薄く, 菊池 パターンが得られなかったため, $\mathrm{FeAl}_{3}$ 相に抢ける $\mathrm{EBSD}$ 解析はできなかった. Fig. 7 に溶接時間 $t=0.400 \mathrm{~s}$ で溶接し た N2/SPCC の溶接界面に抢ける EBSD 解析結果を示す。

(a) に，測定領域の SEM 画像を示す。（b)，(c) 抢よび(d)に は，それぞれ Normal Direction (ND), Rolling Direction (RD) 抢よび Transverse Direction (TD)方向の結晶方位抢よ び結晶粒界を示す。（b）から， $\mathrm{Fe}_{2} \mathrm{Al}_{5}$ は複数の柱状晶から構 成されていることが分かる．柱状晶は被溶接面に垂直方向に 成長し，同じ結晶粒の中に，小傾角粒界が存在している，さ らに, $\mathrm{Fe}_{2} \mathrm{Al}_{5}$ の結晶粒はほぼ赤色調であることから，優れ た配向性を有することが分かった：三つの逆極点図方位マッ プより,アルミニウム合金と鋼をスポット溶接する際に，溶 接界面に打いて生成した $\mathrm{Fe}_{2} \mathrm{Al}_{5}$ 相は溶接面に扔いて, $\{001\}\langle 110\rangle$ 結晶方位を有する. また, $\mathrm{Fe}_{2} \mathrm{Al}_{5}$ の結晶粒の成 長方向 $<001 〉$ は溶接面に垂直方向 $(\mathrm{ND})$ であった.

$\mathrm{Fe}_{2} \mathrm{Al}_{5}$ 相がく001〉方向に沿って成長する理由は次のように 考えられる. 平野らの研究により, $\alpha-\mathrm{Fe}$ 中に扔いて, $\mathrm{Al}$ 原 子の拡散は $\mathrm{Fe}$ 原子の拡散より速いことから, $\mathrm{Fe}_{2} \mathrm{Al}_{5}$ の成長 

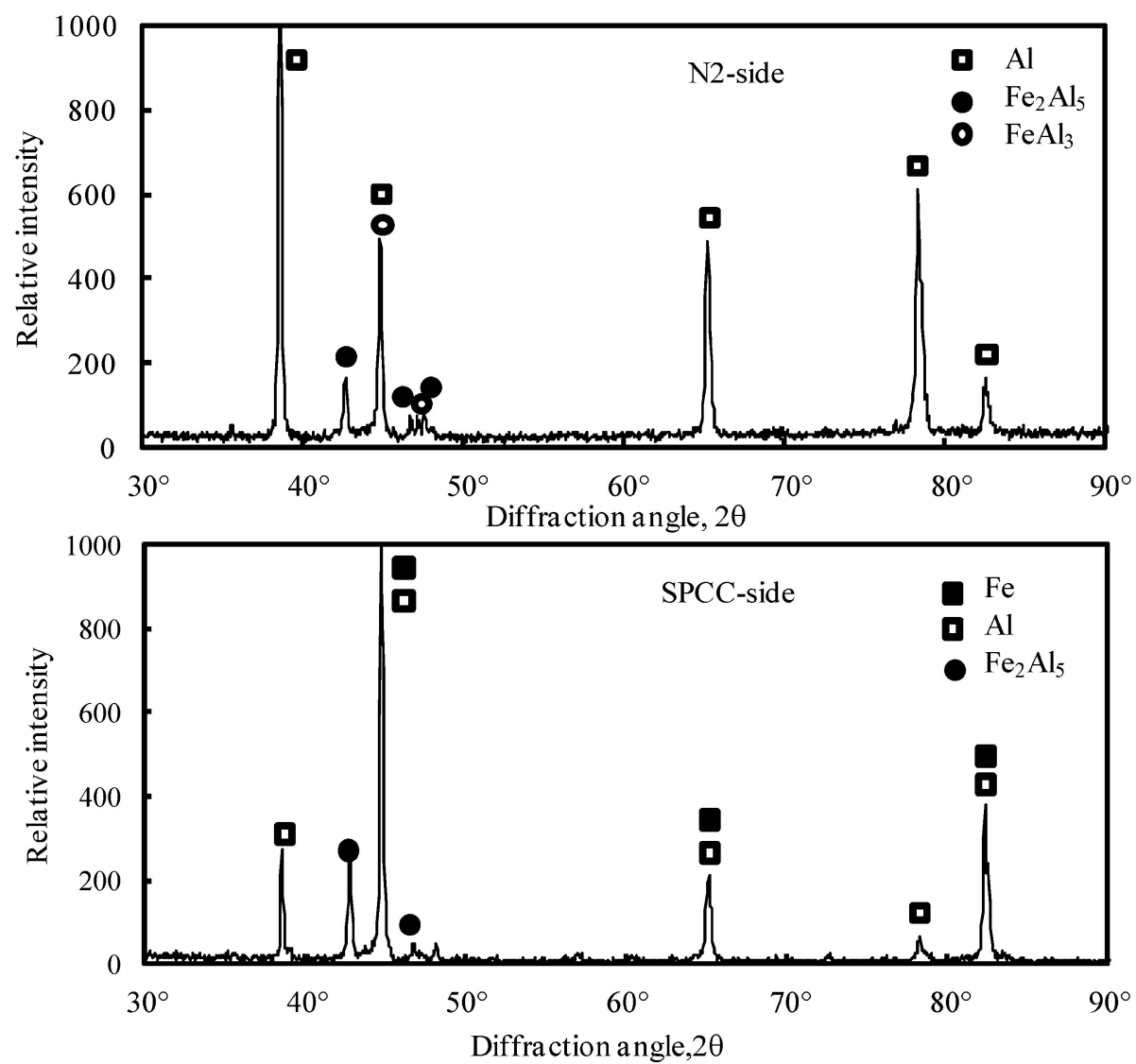

Fig. 6 Results of XRD on the tensile shear fracture of N2/SPCC spot welded joint $(\mathrm{N} 2 / \mathrm{SPCC}, 10.5 \mathrm{kA} \times 1 \mathrm{kN} \times 0.167 \mathrm{~s})$.

には $\mathrm{Al}$ 原子の拡散が支配的であると考えられる17)。また， $\mathrm{Fe}_{2} \mathrm{Al}_{5}$ の結晶構造は Fig. 8 に示すように斜方晶系であり, $c$ 軸の格子点は $\mathrm{Al}$ 原子によって占拠されているが, $\mathrm{Fe}_{2} \mathrm{Al}_{5}$ 格 子中では, 空孔が $30 \%$ 存在している18). したがって, アル ミニウム合金と鋼をスポット溶接する際に，溶接部における $\mathrm{Al}$ 原子は $\mathrm{Fe}_{2} \mathrm{Al}_{5}$ の $c$ 軸 $\langle 001\rangle$ 方向に沿って急激に拡散する.

\subsection{IMC の成長および硬さに及ぼす溶接時間および合金元 素の影響}

$\mathrm{Fe}_{2} \mathrm{Al}_{5}$ および $\mathrm{FeAl}_{3}$ は $\mathrm{OM}$ で区別できないため，ここで は，両者を区別せずに IMCの厚さとして測定した．ナゲッ ト中の IMC の分布状況を調査するため, ナゲットの全長に 亘り約 $8 \mu \mathrm{m}$ 間隔で溶接部における IMCの厚さを測定した.

Fig. 9 に溶接時間 $t=0.067 \mathrm{~s}, 0.134 \mathrm{~s}$ 抢よび $0.200 \mathrm{~s} の$ 場 合の N2/SPCC 溶接部における IMC の厚さ分布とその近似 曲線を示す。溶接時間が短い $t=0.067 \mathrm{~s}$ では, ナゲットの中 央部に括いて，IMC は大きく成長している，また，ナゲッ トの中心を軸として, 両端の IMC が対称に成長している. 溶接時間が $t=0.134 \mathrm{~s}$ では, ナゲット中に IMC は均一に成 長している. 一方, 溶接時間が $t=0.200 \mathrm{~s}$ では, ナゲットの $r=1 / 2$ のところで, IMC が大きく成長している，これは， 溶接時間の増加とともに溶接部は発熱量が大きくなり, 溶接 部が柔らかくなるので, 先端球形の電極がアルミニウム板の 中へ喰い込んでいき, 電極と板の接触面積が増加することに より, 電流密度の分布状況や電極による冷却効果が異なるも のと考えられる.
Fig. 10 に，N2/SPCC，N5/SPCC およびN6/SPCC のナ ゲット $r=0$ および $r=1 / 2$ の溶接界面における IMC の厚さ と溶接時間との関係を示す。 N2/SPCC 溶接部の IMC は $\mathrm{N} 5 / \mathrm{SPCC}$ および N6/SPCC 溶接部の IMC より厚く生成し ている.これは, Table 1 に示したようにN2 アルミニウム 合金の固相線温度が N5 および N6 アルミニウム合金より低 いためと考えられる．溶接する際に，N2アルミニウム合金 の被溶接面が溶融している時間は N5 およびN6 アルミニウ ム合金より長いと考えられるため, N2/SPCC 溶接界面にお いて, Al 原子の拡散時間が最も長いと考えられる．そのた め, N2/SPCC 溶接部の IMC は厚く生成した.

また, IMC 中に拡散した元素も IMC の成長に影響を及ぼ すと考えられるため, EPMA 面分析も行った. Fig. 11 に N2/SPCC，N5/SPCC およびN6/SPCCの溶接界面におけ る EPMA 分析結果を示す. アルミニウム合金母材の合金元 素 $\mathrm{Mg}$ および $\mathrm{Cu}$ の含有量に関係なく，いずれの組み合わせ でも，IMCの中に $\mathrm{Mg}$ 抢よび $\mathrm{Cu}$ の拡散は見られない。一 方，合金元素 Si は IMC の中に拡散していることが分かる. また，アルミニウム合金の中の $\mathrm{Si} の$ 含有量が多いため, IMC 中に拡散した量も多いと考えられる.これは, Al 原子 が $\mathrm{Fe}_{2} \mathrm{Al}_{5}$ 斜方晶系の $c$ 軸に沿って, 拡散するので, アルミ ニウム合金の中に $\mathrm{Si}$ が存在すると, $\mathrm{Si}$ は一部 $\mathrm{Al}$ 原子に置 換し, IMCの中に拡散したものと考えられる. その結果, $\mathrm{Si}$ は $\mathrm{Fe}_{2} \mathrm{Al}_{5}$ の成長を抑制する効果があると考えられる.

次に, IMC の硬さに及ぼす合金元素の影響を調査するた め, 溶接電流 $I=10.5 \mathrm{kA}$, 加圧力 $F=1 \mathrm{kN}$, 溶接時間 $t=$ 

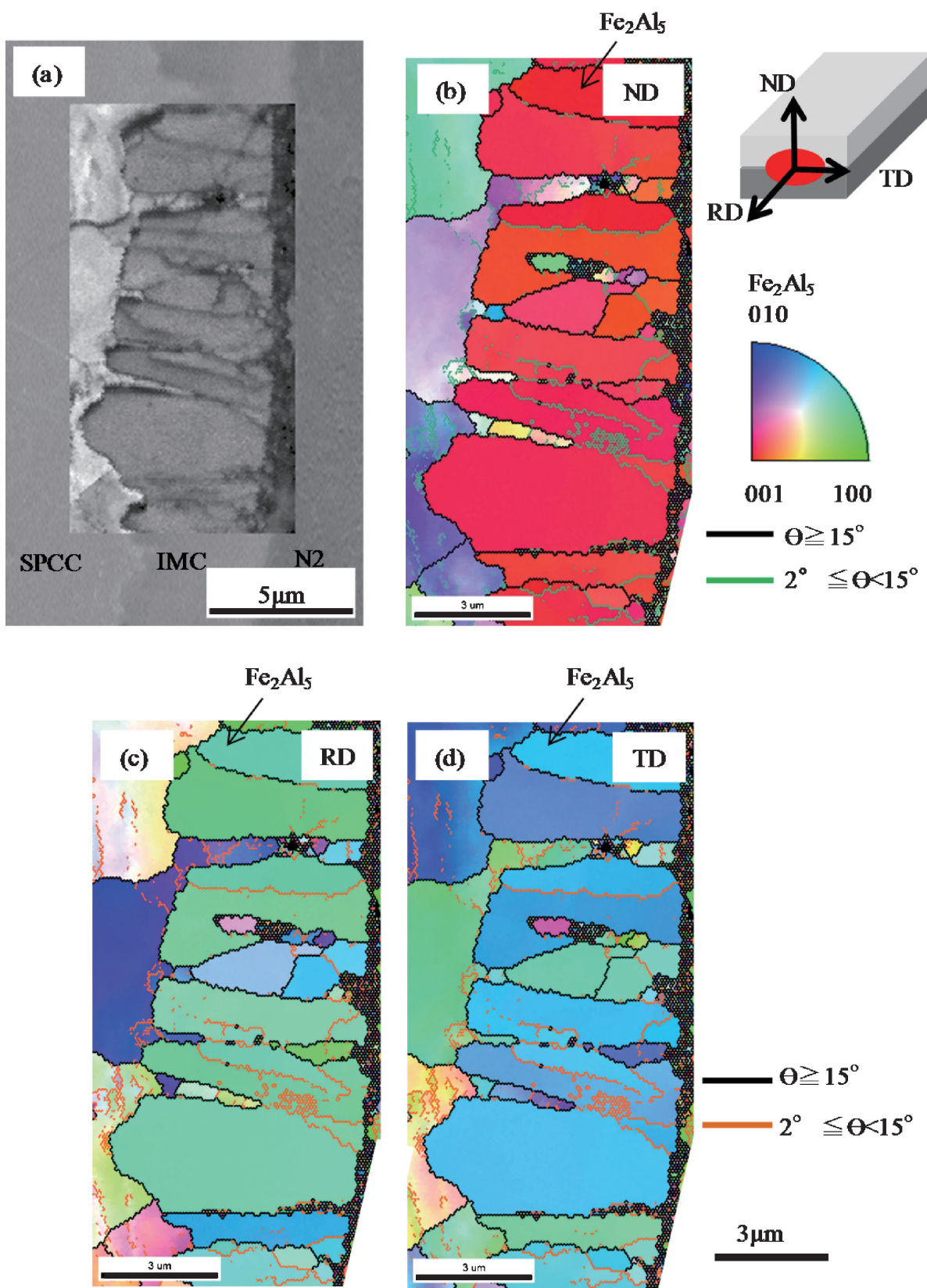

Fig. 7 Inverse pole figure of $\mathrm{Fe}_{2} \mathrm{Al}_{5}$ on weld interface of $\mathrm{N} 2$ aluminum alloy/SPCC spot welded joint $(\mathrm{N} 2 / \mathrm{SPCC}, 10.5 \mathrm{kA} \times 1 \mathrm{kN} \times$ $0.400 \mathrm{~s})$.

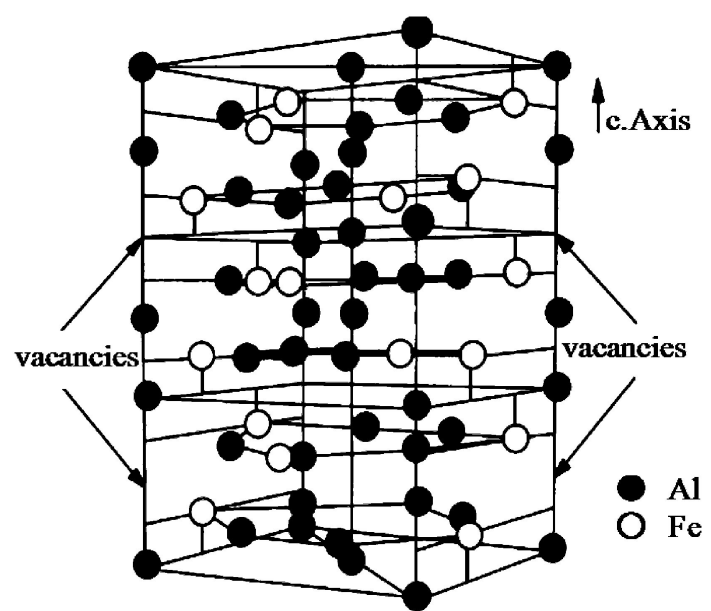

Fig. 8 Three elementary cells of $\mathrm{Fe}_{2} \mathrm{Al}_{5}$ placed next to one another.
$0.400 \mathrm{~s}$ の溶接条件でスポット溶接を行った N2/SPCC，N5/ SPCC 抢よびN6/SPCC 溶接部のIMC の硬さを測定した. 比較のため, 同じ条件で A $1050 / \mathrm{SPCC}$ 溶接部の IMC の硬 さも測定した. Fig. 12 に各材料の溶接部に生成した IMC に対して $2.94 \mathrm{mN}$ の荷重で行ったナノインデンテーション 測定結果を示す。多量の Si が拡散した N5/SPCC および N6/SPCC 溶接部の IMC の硬さは高く, 微量の $\mathrm{Si}$ が拡散し た N2/SPCC 溶接部のIMC の硬さは低い.Si を含有してい ない A1050/SPCC 溶接部の IMC の硬さは最も低い，以上 のことから，IMC 中に拡散した $\mathrm{Si}$ 量が IMC の硬さに影響 を及ぼし，拡散した Si の量が多いほど，IMCの硬さは高く なることが分かった。 

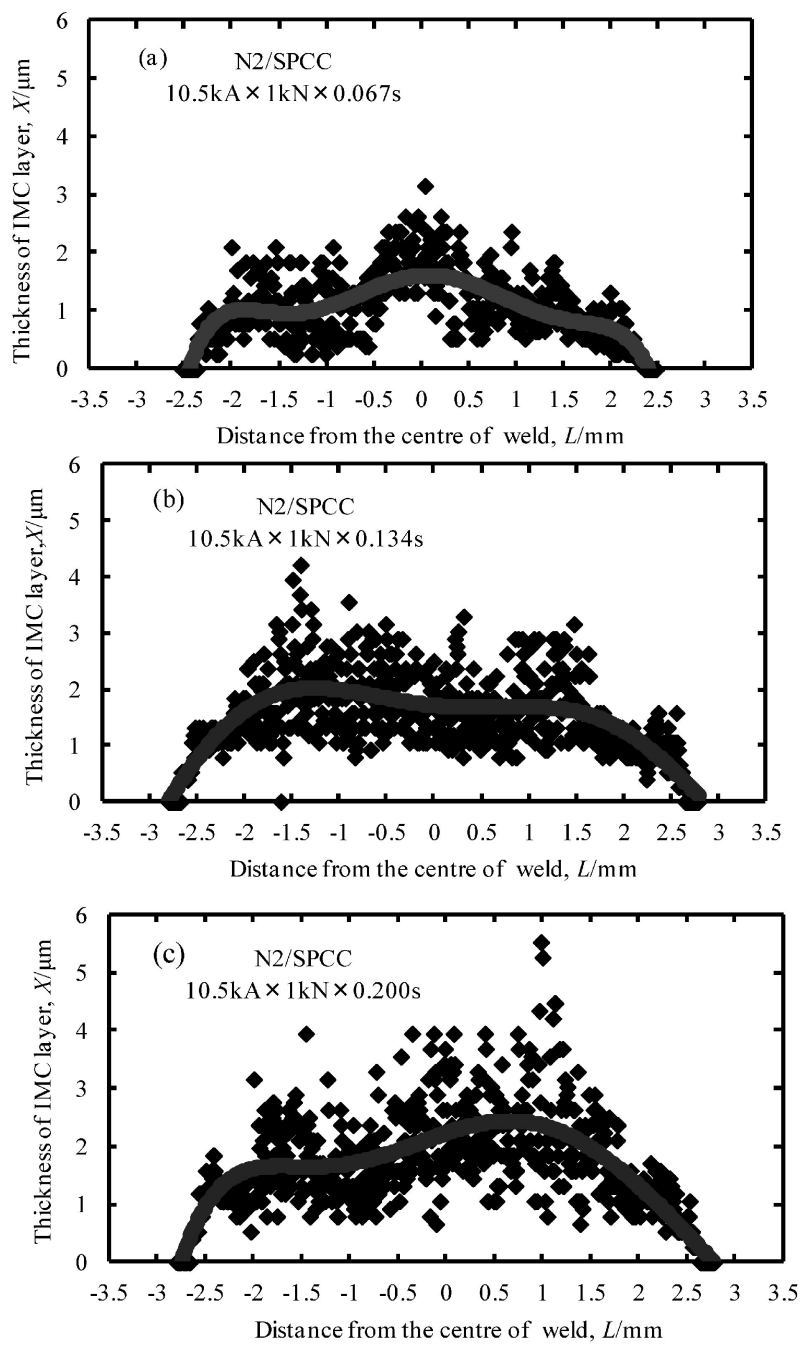

Fig. 9 IMC layer thickness distribution with different welding times; (a) $0.067 \mathrm{~s}$, (b) $0.134 \mathrm{~s}$, (c) $0.200 \mathrm{~s}(\mathrm{~N} 2 / \mathrm{SPCC}, 10.5 \mathrm{kA}$ $\times 1 \mathrm{kN})$.

\section{3 溶接部の引張せん断強度}

\subsection{1 引張せん断強度に及ぼす溶接時間の影響}

Fig. 13 (a) 抢よび(b)に引張せん断後の破面の溶接部の破 断形状を示す（a)のようにSPCC 側にアルミニウム合金が 溶接されたままで残っている場合をプラグ破断とし，（b)の
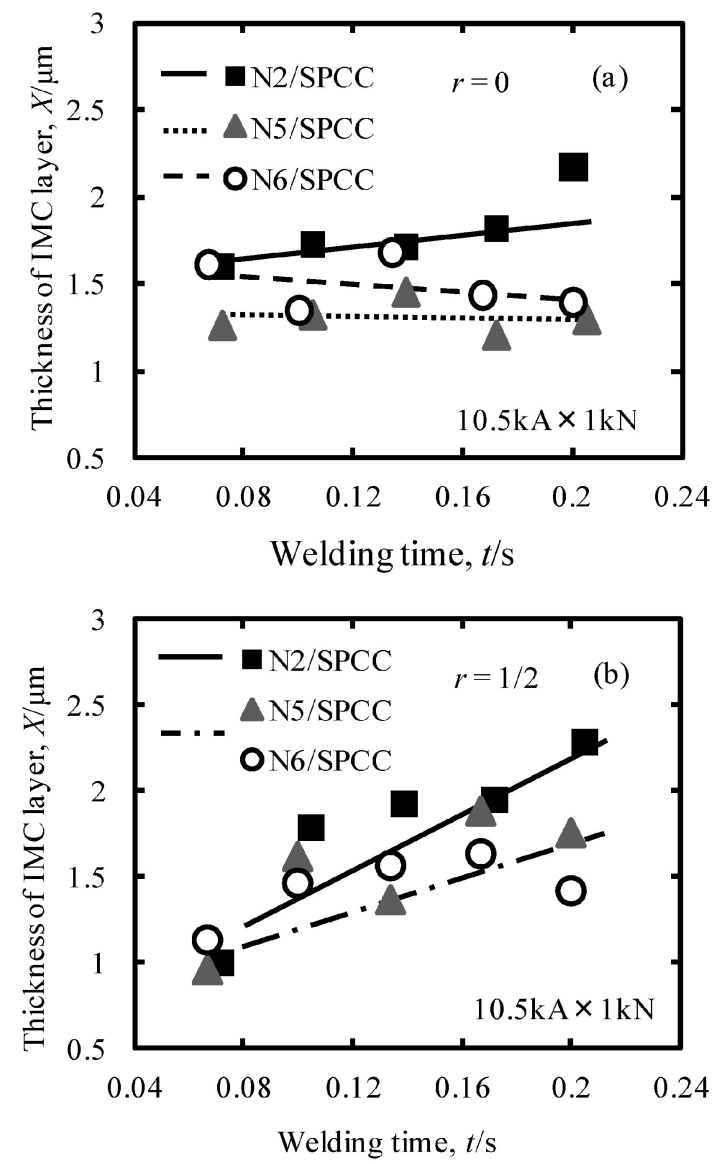

Fig. 10 Effects of welding time and materials on IMC layer thickness; (a) $r=0$, (b) $r=1 / 2(10.5 \mathrm{kA} \times 1 \mathrm{kN})$.
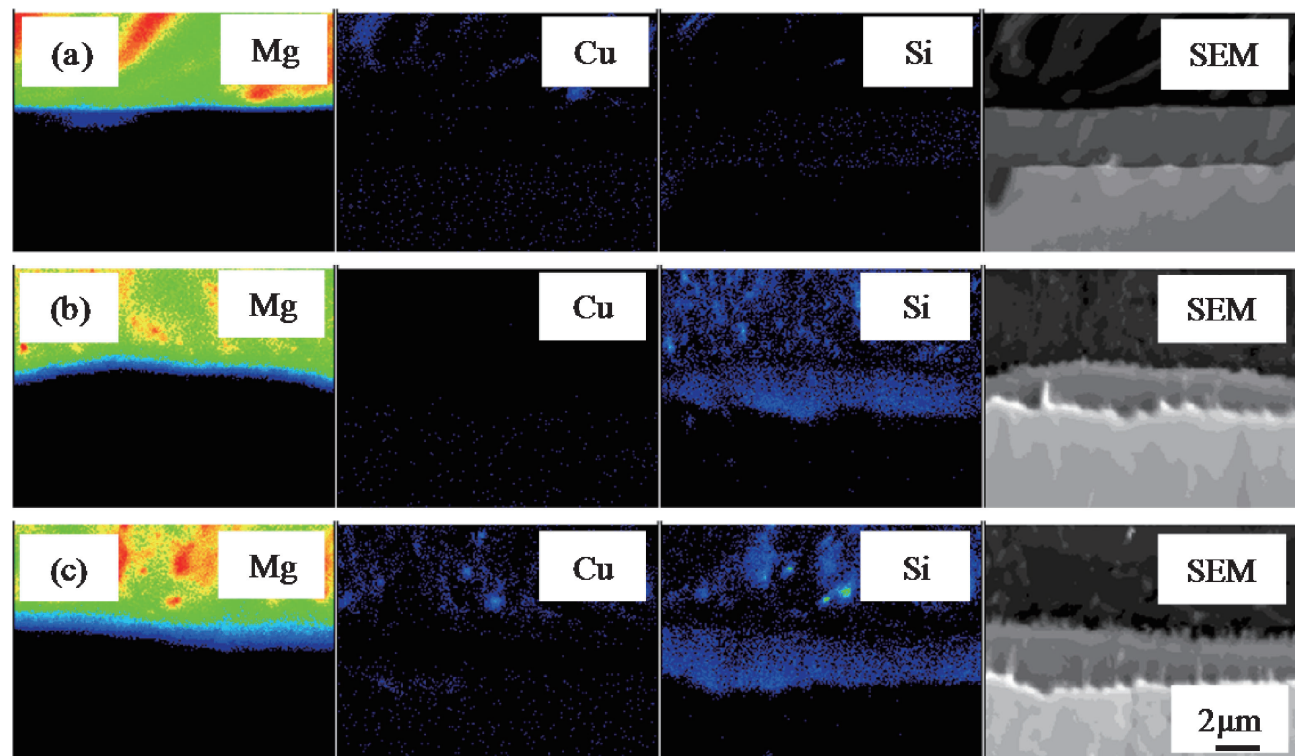

Fig. 11 Results of EPMA mapping analysis; (a) N2/SPCC, (b) N5/SPCC, (c) N6/SPCC $(10.5 \mathrm{kA} \times 1 \mathrm{kN} \times 0.167 \mathrm{~s})$. 


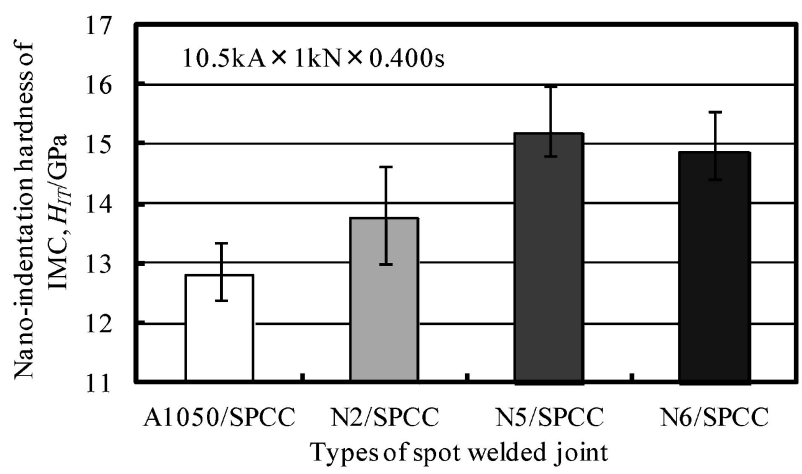

Fig. 12 Nano-indentation hardness of IMC $\mathrm{Fe}_{2} \mathrm{Al}_{5}$ in different spot welded joints $(10.5 \mathrm{kA} \times 1 \mathrm{kN} \times 0.400 \mathrm{~s})$. (a)

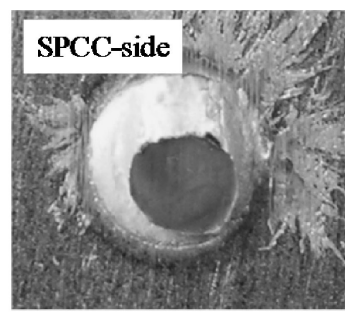

(b)

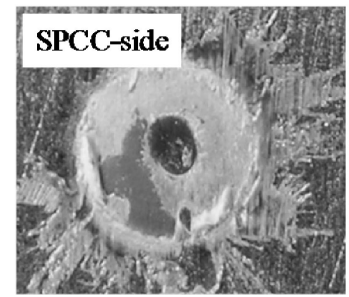

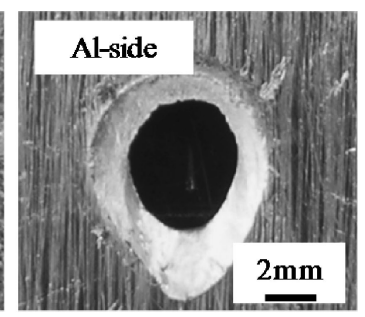

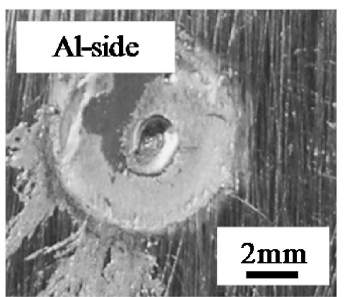

Fig. 13 Macro-photographs of fracture surfaces; (a) plug fracture, (b) shear fracture.

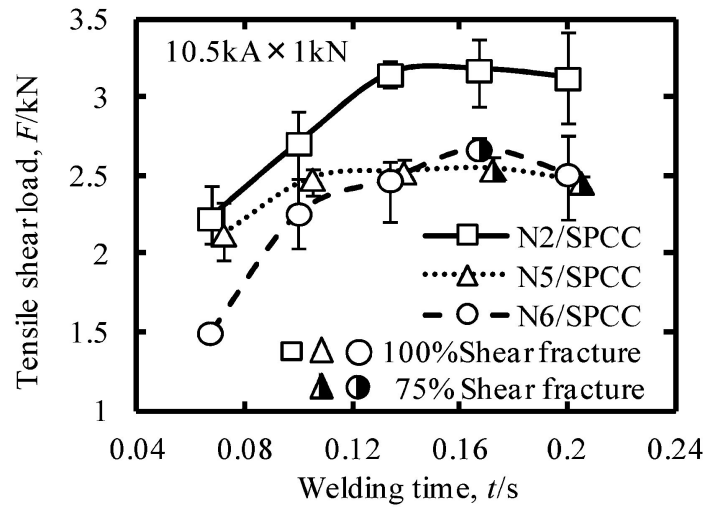

Fig. 14 Effects of welding time and materials on tensile shear load $(10.5 \mathrm{kA} \times 1 \mathrm{kN})$.

\section{ように溶接界面で破断した場合をシャ一破断とした}

Fig. 14 に N2/SPCC，N5/SPCC および N6/SPCC 溶接部 の引張せん断荷重と溶接時間の関係を示す. 図中の白抜きの 記号は $100 \%$ シャ一破断, 半分の白抜き記号は $75 \%$ シャー 破断が発生した場合を示す，N2/SPCC の組み合わせは，す べてシャー破断であった．N5/SPCC およびN6/SPCC の組 み合わせでは，溶接時間 $0.167 \mathrm{~s}$ の場合にプラグ破断が認め られた，溶接時間が短い場合は，ナゲットが急激に成長する ため，引張せん断荷重も急激に増加する．溶接時間 $0.134 \mathrm{~s}$

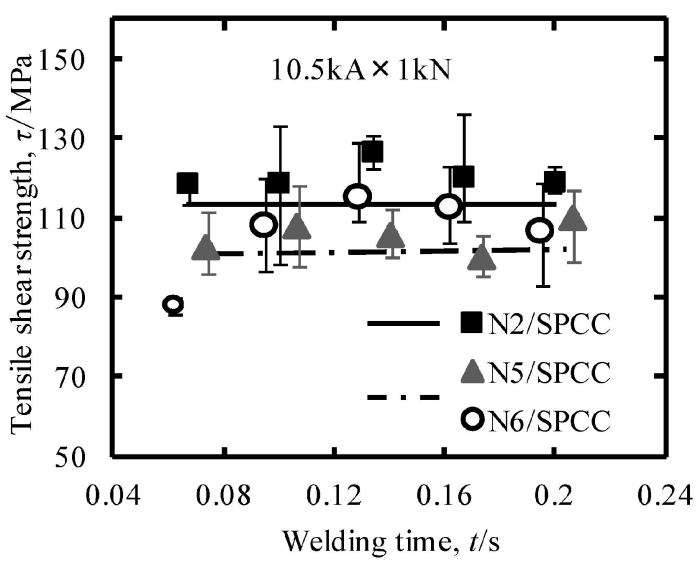

Fig. 15 Effects of welding time and materials on tensile shear strength $(10.5 \mathrm{kA} \times 1 \mathrm{kN})$.

および $0.167 \mathrm{~s}$ で最大の引張せん断荷重が得られた.

シャ一破断が発生した継手の引張せん断荷重と溶接面積を 用い, 引張せ几断強度を求めた. Fig. 15 に引張せ几断強度 に及ぼす溶接時間の影響を示す。同じシャ一破断であるが， $\mathrm{N} 2$ / SPCC 溶接部の引張せん断強度は, N5/SPCC 打よび N6/SPCC の引張せん断強度より高いことが分かる．理由を 調査するため, 引張せん断後の破面を EPMA および EDS 分析を行った。

Fig. 16 (a)に N2/SPCC 溶接部引張せん断破面の SPCC 側 の $\mathrm{Fe}$ 元素の分布状態を示す. EPMA 打よび EDS 分析によ り，破断形態は 3 種類に分類された。それぞれの破断形態 を Fig. 16(b)，(c) 抢よび(d)に示す。（b)は IMC 内部，(c) はアルミニウム合金と $\mathrm{FeAl}_{3}$ の界面，(d) はアルミニウム合 金ナゲット内部で破断している。 また, Fig. 16(a)より, 破 断面積 II 破断面積 I より，大きいことが分かる。そのた め，アルミニウム合金と $\mathrm{FeAl}_{3}$ の界面での破断は，IMC 内 部での破断より発生しやすいと考えられる。これは，アルミ ニウムと $\mathrm{FeAl}_{3}$ の結晶構造が大きく異なっており，かつ熱 膨張係数の差も大きいため, 引張せん断する際に, アルミニ ウム合金と $\mathrm{FeAl}_{3}$ の界面での破断が生じやすいと考えられ る.

各溶接条件の破断面の分析結果により，N2/SPCC の溶接 部は，ほとんどが IIの破断形態，N5/SPCC およびN6/ SPCCの溶接部は，ほとんどが III破断形態となっていた. これは，Table 1 に示したように，約 $2.5 \% \mathrm{Mg}$ を含有する N5 抢よびN6アルミニウム合金の強度は低いため, 引張せ 几断試験を行うと，アルミニウム合金のナゲット内部で破断 し，低い引張せん断強度が得られた。一方，N2アルミニウ ム合金の強度が高く，引張せん断破断は N2 アルミニウム合 金より強度が低い IMC とアルミニウム合金の界面で生じ た．そのため，アルミニウム合金母材の強度は，溶接部の引 張せん断強度に影響していると考えられる，すなわち，合金 元素 $\mathrm{Mg}$ を多量に含有する $\mathrm{N} 2$ アルミニウム合金は，鋼との スポット溶接部の引張せん断強度は高い。一方, $\mathrm{Cu}$ につい ては，顕著な影響は認められなかった。

\subsection{2 引張せん断強度に及ぼす IMC 厚さの影響}

Fig. 17 にアルミニウム合金と SPCC 鋼のスポット溶接部 


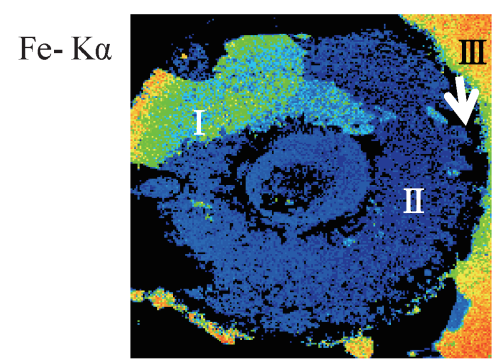

(a)

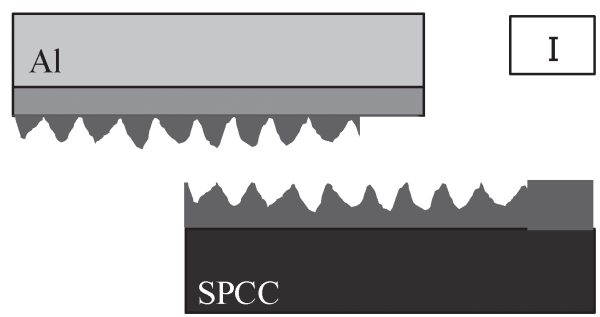

In intermetallic compound

(b)

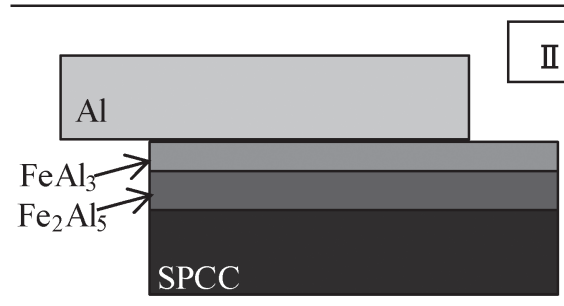

Interface between aluminum and $\mathrm{FeAl}_{3}$

(c)

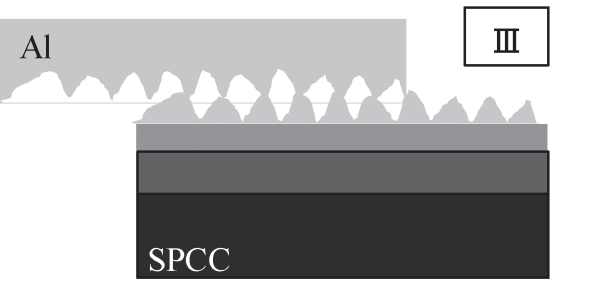

In nugget of a luminum side

(d)

Fig. 16 Fracture modes observed in tensile shear testing of N2 aluminum alloy/SPCC spot welded joint.

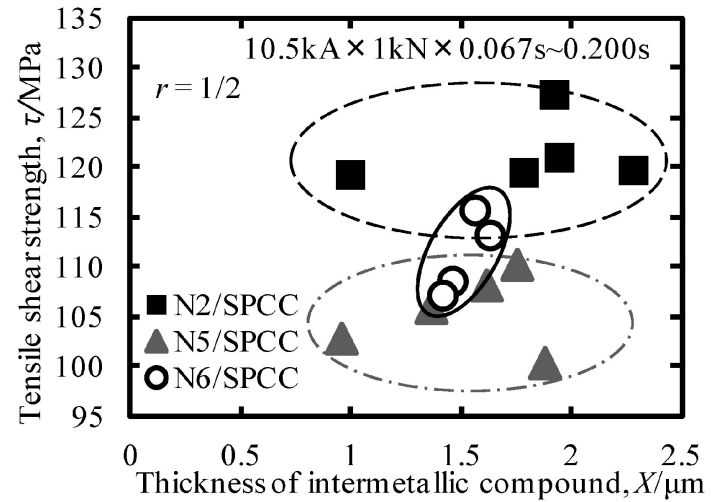

Fig. 17 Effect of thickness of IMC on tensile shear strength $(10.5 \mathrm{kA} \times 1 \mathrm{kN} \times 0.067 \mathrm{~s} \sim 0.200 \mathrm{~s})$.

の引張せん断強度に及ぼす IMC 厚さの影響を示す. IMC の 厚さが同じでも, 引張せん断強度に大きな違いがある.これ はアルミニウム合金の種類の影響が顕著に生じているためで ある. 同一のアルミニウム合金と鋼の組み合わせに抏て は，引張せん断強度に及ぼす IMC 厚さの影響は見られな い. 迎らは，真空圧延接合法により作製したアルミニウムク ラッド鋼 (99.99\% Al/SS400)に対して, アルミニウムの融点 直下をでの温度に抢いて加熱処理を行い，接合部に形成され た IMC の成長挙動と接合部のせん断強さについて検討した. IMC が約 $1.5 \mu \mathrm{m}$ 以上に成長すると, せん断強度は急激に低 下する ${ }^{14)}$. すなわち, IMC の厚さは一定の值になると, 接 合部強度が急激に低下する. 一方, 本研究のアルミニウム合 金と鋼のスポット溶接部に生成した IMC はほとんど $2 \mu \mathrm{m}$ 以下であったため, 溶接部の引張せん断強度に及ぼす IMC の影響は非常に小さいことが明らかになった。
4. 結 論

化学組成が異なるアルミニウム合金 N2，N5，N6 および 一般冷間圧延鋼板 SPCC を供試材として, スポット溶接 し, 溶接部の組織および溶接部の強度に及ぼす接合条件およ び合金元素の影響について検討した．主な結果は以下のとお りである。

（1）アルミニウム合金と鋼のスポット溶接界面には，アル ミニウム合金側には, 薄い針状の $\mathrm{FeAl}_{3}$, 鋼側には不均一な 舌状の $\mathrm{Fe}_{2} \mathrm{Al}_{5}$ が生成していることが分かった。また， $\mathrm{Fe}_{2} \mathrm{Al}_{5}$ の結晶粒の成長方向 $\langle 001\rangle$ は溶接面に垂直方向 (ND) であった． $\mathrm{Fe}_{2} \mathrm{Al}_{5}$ 相は溶接面において，\{001\}〈110〉結晶方 位を有していることが明らかになった。

（2）金属間化合物の中に, 合金元素 $\mathrm{Mg}$ および $\mathrm{Cu}$ の拡散 は確認できなかったが，合金元素 Si の拡散が認められた。 そして, $\mathrm{Si}$ の拡散によって, 金属間化合物の厚さは減少 し，その硬さは高くなった。

（3）引張せん断荷重は, 溶接時間の増加とともに増大し, 溶接時間 $0.134 \mathrm{~s}$ および $0.167 \mathrm{~s}$ の場合に扔いて最大荷重が 得られた。

（4）引張せん断強度は，合金元素 $\mathrm{Mg}$ を多量に含有する アルミニウム合金と鋼とのスポット溶接部において最も高い 值を示した。

（5）金属間化合物の厚さは $2 \mu \mathrm{m}$ 以下と薄いため, 溶接部 の引張せん断強度に及ぼす金属間化合物の影響は小さかった。

本研究を遂行するに当たり, 九州工業大学機器分析セン ターの三好規子技術職員には EPMA 分析においてご協力頂 きました. 福岡県機械電子研究所には引張せん断試験におい てご協力を頂きました．ご協力頂いた方々に深く謝意を表し ます。 


\section{文献}

1) T. Ohtani and J. Takai: Materia Japan 39(2000) 878-882.

2) K. Fukizawa, S. Koike and K. Sibata: Materia Japan $39(2000)$ 17-24.

3) M. Maruyama: Materia Japan 39 (2000) 31-37.

4) K. Mori: Journal of JSAE 61 (2007) 13-17.

5) S. Seiji: Journal of JSAE 61(2007) 24-29.

6) M. Watanabe, T. Ookawa and S. Kumai: J. JILM 57 (2007) 536541.

7) K. J. Lee, S. Kumai, N. Kawamura, N. Ishikawa and K. Furuya: Mater. Trans. 48(2007) 1396-1405.

8) T. Ogura, K. Ueda, Y. Saito and A. Hirose: J. JILM 61 (2011) 250-254.

9) G. Eggeler, W. Auer and H. Kaesche: J. Mater. Sci. 21 (1986) 3348.

10) T. Ogura, H. Umeshita, Y. Saito and A. Hirose: Quarterly
Journal of JWS 27 (2009) 174-178.

11) Y. Saito, H. Umeshita, T. Ogura and A. Hirose: Quarterly Journal of JWS 27 (2009) 187-191.

12) T. Hamao, T. Yamaguchi, H. Ohtani, K. Nishio, A. Fukumoto and Y. Okajima: Preprints of the National Meeting of JWS, (2010) pp. 138-139.

13) R. Qiu, C. Iwamoto and S. Satonaka: J. Mater. Process. Technol. 209(2009) 4186-4193.

14) S. Mukae, K. Nishio, M. Katoh, T. Inoue and K. Sumitomo: Quarterly Journal of JWS 12(1994) 528-533.

15) N. Wang, T. Yamaguchi and K. Nishio: Applied Mechanics and Materials 117-119(2012) 1895-1899.

16) W. Zhang, D. Sun, L. Han, W. Gao and X. Qiu: ISIJ Int. 51 (2011) $1870-1877$.

17) K. Hirano and A. Hishinuma: J. Japan Inst. Metals 32 (1968) 516-521.

18) A. Bahadur and O. N. Mohanty: Mater. Trans., JIM 32(1991) 1053-1061. 